\title{
AN EXPERIMENTAL STUDY TO EVALUATE THE EFFECTIVENESS OF REMINISCENCE THERAPY ON DEPRESSION AMONG THE ELDERS RESIDING IN A SELECTED OLD AGE HOME
}

\author{
Mr. Nishad.T .N* | Dr. S. Madhavi** \\ *Ph.D Scholar, OPJS University Rawatsar, Rajasthan, India. \\ **Professor \& Principal, KMCH College of Nursing, Coimbatore, Tamilnadu. India. \\ DOI: http://doi.org/10.47211/trr.2019.v05i02.001 \\ Received $5^{\text {th }}$ October 2019, Accepted $5^{\text {th }}$ December 2019, Published $20^{\text {th }}$ December 2019
}

\section{ABSTRACT}

An experimental study to assess the effectiveness of reminiscence therapy in reducing the level of depression among the elders in a selected old age home Objectives of the study: To identify the level of depression among the senior citizen in the old age home. To determine the effect of reminiscence therapy oni depression level among the senior citizen in the old age home, To associate the between post level of depression with selected demographic variables. Majority (50\%) of the samples belong to the age group of $70-79$ years where as only $16.7 \%$ of the sample belonged to the age of the age of group of $80-89$ years. Male (76-7\%) dominated the female (23.3\%) and majority of them (90\%) belonged to Hindu community. Large portions (40\%) of the sample were employed in government sector in the pre-retirement employment status. In contract only $6.7 \%$ were employed in private sector. The number of literates was surprisingly higher (70\%) than the illiterate (30\%). Widow/widower (73.3\%) dominated the sample size. For most of the elders the income (56.7\%) and support group (66.7\%) was inadequate. The distribution of elderly according to level of depression before and after the manipulation in which $66.7 \%$ of the samples of the samples had showed moderate level of depression in the pretest. In contrast, majority (73.3\%) of the sample experienced only mild level of depression in the post test. The mean post test level of depression score (13.9) was lesser than the mean pre-test level of depression score (18.93). The obtained $t$ value 31.25 was statistically highly significant at 0.05 levels.

There was no statistically significant association between the level of depression and demographic variables of the elderly.

Keywords: Elderly people, Old age home, Depression, Reminiscence therapy

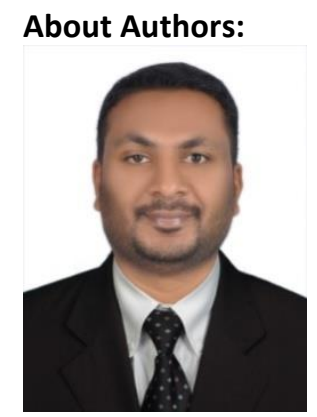

Author Mr. Nishad. T. N is a Research Scholar in OPJS University, in Rajasthan, India. He has attended various Seminars and conferences.

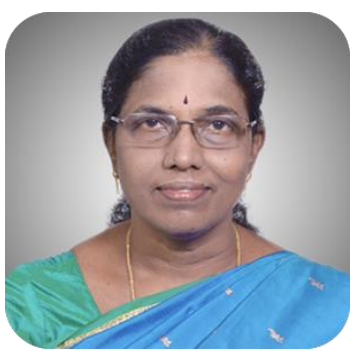

Author Dr. S. Madhavi is an active researcher with many publications in her name. She has attended and organised various National and International conferences and has given extensive lectures. At present she is Professor cum Principal of KMCH College of Nursing, Coimbatore, Tamil Nadu, India. 


\section{INTRODUCTION}

There are several changes that occur as part of the normal aging process. These life events or transitions disrupt or threaten to change an individual's normal routine and activities and consequently can affect an individual's wellbeing (McLeod, 1996). Life events which affect the majority of the senior are retirement, changes in income level, physical changes (including illness) and changes in social support networks (including caring for another individual and coping with the death of a spouse and peers). These events may negatively affect senior's wellbeing by increasing social isolation, loneliness, depression and suicidal thought. Among the mental health problems, depression is especially prevalent among older adults. In a large retrospective self-reported study, $17.8 \%$ of females and $9.4 \%$ of males who were older than 60 years were diagnosed with lifetime depression based on the DSM-III -R criteria (Barry et al., 1998). In addition, epidemiological studies show that the death rates for individuals who are older than 55 years and with a diagnosis of Major depressive disorder will increase four fold (DSM - IV TRTM, 2000) Therefore, obtaining adequate health care resources in case of older adults is a challenge and critical issue in the $21^{\text {st }}$ century.

Up to $20 \%$ of older people live in residential or nursing homes towards the end of their lives. Entry into such institutions is often due to combinations of medical, social and psychological factors. The prevalence of depression in the population is high, though there is an extensive literature to suggest that depression is under diagnosed and under treated and that neither primary nor secondary care services are well coordinated to treat this common condition. Untreated depression increases mortality up to a factor of two - fold in older people, for both cardiac and non-cardiac causes (Eisses. et.al).

\section{STATEMENT OF THE PROBLEM}

An experimental study to evaluate the effectiveness of reminiscence therapy on depression among the elders residing in a selected old age home at Madurai.

\section{Objectives of the study}

1. To identify the level of depression among the elders residing in selected old age home before and after reminiscence therapy.

2. To determine the effectiveness of reminiscence therapy in terms of reduction of depression among the elders residing in selected old age home at Madurai.

3. To estimate the association between the level of depression with selected demographic variables such as age, gender, education, pre-retirement status, marital status, religion, support group, occupation and source of income of the elderly.

Hypotheses:

All hypotheses were tested at 0.05 level of significance.

- $\quad \boldsymbol{H 1}$ - The mean post test depression score will be significantly lesser than the mean pre test score of the elders who had reminiscence therapy.

- H2- There will be significant association between the level of depression and selected demographic variables such as age, gender, education, marital status, pre-retirement employment status, occupation, religion, support group and source of income of the elderly.

\section{Assumption:}

1. Most of the elderly suffer depression.

2. Reminiscence therapy assists the elderly to resolve conflicts, deals with past losses, recognize and appreciate inner resources and find meaning in the significant past life events.

3. Reminiscence Therapy has no adverse effect on the elderly.

4. Nurses, particularly psychiatric nurses have an important role in reduction of depression among the elderly in various settings.

RESEARCH DESIGN: The research design used was one group pre - test post - test pre experimental design.

\begin{tabular}{|c|c|c|c|}
\hline Group & Pre Test & Treatment & Post Test \\
\hline Experimental Group & $\mathrm{O}_{1}$ & $\mathrm{X}$ & $\mathrm{O}_{2}$ \\
\hline
\end{tabular}




\section{POPULATION:}

The target population of the study was the elders residing in a selected old age home at Madurai.

\section{SAMPLE:}

Samples were the elderly who had either mild or moderate depression and were residing in a selected old age home at Maduari \& those who fulfilled the inclusion criteria.

SAMPLE SIZE: The sample size was 30

SAMPLING TECHNIQUE: The sampling techniques used were total enumerative sampling.

\section{DESCRIPTION OF THE TOOL}

PART - 1: It included the demographic characteristics of the elderly people, such as age, gender, religion, education, pre - retirement employment status, support group and source of income.

PART - 2: Geriatric Depression Scale was used to assess the level of depression among the elderly people.

The Geriatric Depression Scale developed by TL Brink et al is a 30 item self-rated scale. The geriatric Depression Scale has been reported to be a useful screen for depression in elderly population.

\section{SCORING PROCEDURE:}

Each item of the Geriatric Depression Scale was answered either "yes" or "No". There were 20 items which indicated depression when answered yes and 10 items which indicated depression when answered no (item $1,5,7,9,15,19,21,27,29,30)$ A total score provided which consisted of one point from each depressive answer. Non depressive answers were scored zero and did not add to the total score. The total score was interpreted as follows:

Normal

Mild depression

Moderate depression

$0-9$

Severe depression

$10-16$

$17-23$

Table - 1

Frequency distribution of demographic characteristics of the elderly.

\begin{tabular}{|c|c|c|}
\hline Demographic Variables & $\mathbf{F}$ & $\%$ \\
\hline Age : $60-69$ Years & 10 & 33.3 \\
\hline 70 - 79 Years & 15 & 50 \\
\hline $80-89$ Years & 5 & 16.7 \\
\hline Gender: Male & 23 & 76.7 \\
\hline Female & 7 & 23.3 \\
\hline Religion : Hindu & 27 & 90 \\
\hline Christian & 1 & 3.3 \\
\hline Muslim & 2 & 6.7 \\
\hline \multicolumn{3}{|l|}{ Pre- Retirement Employment Status: } \\
\hline \multicolumn{3}{|l|}{$\overline{\text { Unemployed }}$} \\
\hline \multicolumn{3}{|l|}{ Self employed } \\
\hline \multicolumn{2}{|l|}{ Employed by others } & 20 \\
\hline - Government & 12 & 40 \\
\hline - $\quad$ Private & 2 & 6.7 \\
\hline$\bullet \quad$ Coolie & 5 & 16.6 \\
\hline Education : Literate & 21 & 70 \\
\hline Illiterate & 9 & 30 \\
\hline \multicolumn{3}{|l|}{ Marital Status: } \\
\hline Married \& Separate & 3 & 10 \\
\hline Divorced & 3 & 10 \\
\hline Unmarried & 2 & 6.7 \\
\hline Widow/ Widower & 22 & 73.3 \\
\hline
\end{tabular}


Table -2 predicts that majority (50\%) of the samples belong to the age group of $70-79$ whereas only $16.7 \%$ of the sample belonged to the age of group, of $80-89$ years. Male $(76.7 \%)$ dominated the female $(23.3 \%)$ and majority of them (90\%) belonged to Hindu community. Large portions (40\%) of the sample were employed in government sector in the pre-retirement employment status. In contrast only $6.7 \%$ were employed in private sector. The number of literates was surprisingly higher (70\%) than the illiterate (305) Widow/ Widower (73.3\%) dominated the sample size. For most of the elders the income (56.7\%) and support group (66.7\%) was inadequate.

Table - 2:- Distribution of the Elderly According to the Level of Depression in the Pre and Post test.

\begin{tabular}{|l|c|c|c|c|}
\hline \multirow{2}{*}{$\begin{array}{c}\text { Level of } \\
\text { Depression }\end{array}$} & \multicolumn{2}{|c|}{ Pre-test } & \multicolumn{2}{c|}{ Post - Test } \\
\cline { 2 - 5 } & F & \% & F & $\%$ \\
\hline Mild (10-16) & 10 & 33.3 & 22 & 73.3 \\
\hline Moderate (17-23) & 20 & 66.7 & 8 & 26.7 \\
\hline Severe (24-30) & 0 & 0 & 0 & 0 \\
\hline
\end{tabular}

Table - 2: statistically predicts the distribution of elderly according to level of depression before and after the manipulation in which $66.7 \%$ of the samples had showed moderate level of depression in the pretest . In contrast, majority (73.3\%) of the sample experienced only mild level of depression in the post test.

TABLE -3 Comparison of the Level of Depression Before and After Reminiscence Therapy.

\begin{tabular}{|c|c|c|c|c|}
\hline Variable & Mean & Mean Difference & $\begin{array}{c}\text { Standard } \\
\text { Deviation }\end{array}$ & T value \\
\hline Pre - test & 18.93 & 5.03 & 2.76 & 2.72 \\
Post - test & 13.9 & & $31.25^{* * *}$ \\
\hline (***P0.001)
\end{tabular}

To compare the mean pretest and post test level of depression of the elderly, the null hypothesis was stated as follows.

There will be no significant difference between the level of depression and Reminiscence Therapy at 0.05 level of significance. The hypothesis was tested using paired - $t$ test method.

Table - 3 portrays that the mean post test level of depression score (13.9) was lesser than the mean pretest level of depression score (18.93). The obtained t-value 31.25 was statistically highly significant at 0.01 level. This illustrates that the mean difference of 5.03 is a true difference and has not occurred by chance. So the researcher rejects the null hypothesis and accepts the research hypothesis. 
Table - 4:- Association between Post Test Level of Depression and Demographic variables of the Elderly.

\begin{tabular}{|c|c|c|c|c|c|}
\hline \multirow{2}{*}{ Demographic variables } & \multicolumn{5}{|c|}{ Post test } \\
\hline & Mild & Moderate & Severe & Total & Chi Square \\
\hline \multicolumn{6}{|l|}{ Age: } \\
\hline$>60-69$ Years & 7 & 3 & 0 & 10 & \multirow{3}{*}{$1.14 \#$} \\
\hline$>\quad 70-79$ Years & 11 & 4 & 0 & 15 & \\
\hline$>\quad 80-89$ Years & 4 & 1 & 0 & 5 & \\
\hline \multicolumn{6}{|l|}{ Gender: } \\
\hline$>$ Male & 18 & 5 & 0 & 23 & \multirow[t]{2}{*}{$0.60 \#$} \\
\hline$>$ Female & 4 & 3 & 0 & 7 & \\
\hline \multicolumn{6}{|l|}{ Religion : } \\
\hline$>$ Hindu & 19 & 8 & 0 & 27 & \multirow{3}{*}{$1.23 \#$} \\
\hline$>$ Christian & 1 & 0 & 0 & 1 & \\
\hline$>$ Muslim & 2 & 0 & 0 & 2 & \\
\hline \multicolumn{6}{|l|}{ Pre- Retirement } \\
\hline Employment Status: & & & & & \multirow{4}{*}{$2.12 \#$} \\
\hline$>$ Unemployed & 3 & 2 & 0 & $\begin{array}{l}5 \\
6\end{array}$ & \\
\hline$>$ Self & 4 & 2 & 0 & 6 & \\
\hline$>$ Employed by others & 15 & 4 & 0 & 19 & \\
\hline \multicolumn{6}{|l|}{ Education : } \\
\hline$>$ Literate & 18 & 3 & 0 & 21 & \multirow[t]{2}{*}{ 2.92\# } \\
\hline$>$ Illiterate & 4 & 5 & 0 & 9 & \\
\hline \multicolumn{6}{|l|}{ Marital Status: } \\
\hline$>$ Separate & 4 & 2 & 0 & 6 & \multirow[t]{2}{*}{$0.16 \#$} \\
\hline$>$ Single & 18 & 6 & 0 & 24 & \\
\hline \multicolumn{6}{|l|}{ Income: } \\
\hline$>$ Adequate & 8 & 5 & 0 & 13 & \multirow[t]{2}{*}{$0.088 \#$} \\
\hline$>$ Inadequate & 11 & 6 & 0 & 17 & \\
\hline \multicolumn{6}{|l|}{ Support Group: } \\
\hline$>$ Adequate & 7 & 3 & 0 & 10 & $0.08 \#$ \\
\hline$>$ Inadequate & 13 & 7 & 0 & 20 & \\
\hline
\end{tabular}

$\mathrm{N}=30$

\# Nor significant at 0.05 level.

To find out an association between level of depression and demographic variables of the elderly, the null hypothesis was showed as follows.

There will be no significant relationship between level of depression and selected variables such as age, gender, education, religion, pre-retirement employment status, marital status, support group and source of income.

Table - 4 shows that there was no statistically significant association between the level of depression and demographic variables of the elderly. The researcher accepts the null hypothesis and rejects the research hypothesis.

\section{Recommendations for Further Study}

On the basis of the present study the following recommendations have been made for the further study.

1. A longitudinal study can be undertaken to see the long term effect of Reminiscence Therapy in reducing the level of depression.

2. The same study can be conducted by using the control group to see the effectiveness of Reminiscence therapy.

3. It can be conducted with large sample to generalize the findings.

4. A comparative study can be conducted among individual Reminiscence Therapy and group Reminiscence Therapy.

5. A similar kind of study can be conducted to assess the effect of Reminiscence Therapy on dementia, self-esteem, family coping and life satisfaction.

6. A qualitative approach can be applied in studying the effects of Reminiscence Therapy on depression.

7. A similar kind of study can be undertaken to evaluate the effect of Creative Reminiscence Therapy on depression among the elders. 


\section{REFERENCE}

Books:

1. Carnevali, D.L. (1993). Nursing Management for the Elderly ( $3^{\text {rd }}$ ed.,) Philadelphia: Lippincott.

2. Redfern, S.J. (1991) Nursing Elderly People ( $2^{\text {nd }}$ ed.). London: Livingstone.

3. Lueckenotte, A.G (1995) Gerontology Nursing ( $1^{\text {st }}$ ed.). U.S.A. Mosby Publication.

4. Townsend, M.(1996) Psychiatric Mental Health Nursing $\left(2^{\text {nd }}\right.$ ed.) Philadelphia: Davis company.

5. Hungler, B.P., \& Polit, D.F. (1999) Nursing Research ( $6^{\text {th }}$ ed.,) Philadelphia: Lippincott.

6. Gurumani, N. (2004) An Introduction to Biostatistics $\left(1^{\text {st }}\right.$ ed.) India: MJP Publishers.

7. Steffi, B.M. (1984). Handbook of Geronotological Nursing $\left(1^{\text {st }}\right.$ ed). U.S.A: Van Nostand Reinhold Company.

8. Eliopoulos, C. (1987). Gerontologic Nursing ( $2^{\text {nd }}$ ed) Philadephia: Lippincott.

9. Mildred, P. (1998). Nursing Care of Older Adult. ( $2^{\text {nd }}$ ed.). U .S.A. Harwal Publishing Company.

Journals :-

1. Hsieh, F.H., \& Jy wang , J. (2003) Effects of Reminiscence Therapy on Depression in Older Adults . International Journal of Nursing Studies: (40) : $335-345$.

2. Wang, J.J., ChuanHsu, Y., \& Fen Cheng, S (200) Efects of reminiscence therapy in promoting mental health of Taiwanese Elderly. International Journal of Nursing Studies; (42): 31 -36 .

3. Lashley, M.E. (1993). The painful Side of Reminiscence. Geriatric Nursing ; 14(3) : 1378-141.

4. Beaton, S.R. (1980). Reminiscence in Old Age. Nursing forum ; 19(3): 270-277.

5. Youssef, F.A. (1990). The Impact of Group reminiscence Counseling on a Depressed Elderly Population . Nurse Practitioner, (15): 34-37.

6. Burnside, I., \& Haight, B. (1994) Reminiscence and Life review: Therapeutic Introversion for Older People. Nurse Practitioner, 19(4): 55-61.

7. Bramlett, M.H. \& Gueldner, S.H. (1993) Reminiscence: A Viable option to Enhance Power in Elders, Clinical Nurse Specialist: 7(2): 68-73. 